\title{
A practical approach to low protein diets for patients with chronic kidney disease in Cameroon
}

\author{
Gloria Enow Ashuntantang ${ }^{1 *}$, Hermine Fouda ${ }^{2}$, Francois Folefack Kaze ${ }^{3}$, Marie-Patrice Halle ${ }^{4}$, Crista Tabi-Arrey ${ }^{5}$ and \\ Magloire Biwole-Sida ${ }^{6}$
}

\begin{abstract}
Cameroon is a low-middle income country with a rich diversity of culture and cuisine. Chronic kidney disease (CKD) is common in Cameroon and over $80 \%$ of patients present late for care, precluding the use of therapies such as low protein diets (LPDs) that slow its progression. Moreover, the prescription of LPDs is challenging in Cameroon because dieticians are scarce, there are no renal dieticians, and people often have to fund their own healthcare. The few nephrologists that provide care for CKD patients have limited expertise in LPD design.

Therefore, only moderate LPDs of $0.6 \mathrm{~g}$ protein per kg bodyweight per day, or relatively mild LPDs of $0.7-0.8 \mathrm{~g}$ protein per $\mathrm{kg}$ bodyweight per day are prescribed. The moderate LPD is prescribed to patients with stage 3 or 4 CKD with non-nephrotic proteinuria, no evidence of malnutrition and no interrcurrent acute illnesses. The mild LPD is prescribed to patients with stage 3 or 4 CKD with nephrotic proteinuria, non-symptomatic stage 5 CKD patients or stage 5 CKD patients on non-dialysis treatment. In the absence of local sources of amino and keto acid supplements, traditional mixed LPDs are used. For patients with limited and sporadic access to animal proteins, the prescribed LPDs do not restrict vegetable proteins, but limit intake of animal proteins (when available) to $70 \%$ of total daily protein intake. For those with better access to animal proteins, the prescribed LPDs limit intake of animal proteins to 50-70 \% of total daily protein intake, depending on their meal plan. Images of $100 \mathrm{~g}$ portions of meat, fish and readily available composite meals serve as visual guides of quantities for patients. Nutritional status is assessed before LPD prescription and during follow up using a subjective global assessment and serum albumin. In conclusion, LPDs are underutilised and challenging to prescribe in Cameroon because of weakness in the health system, the rarity of dieticians, a wide diversity of dietary habits, the limited nutritional expertise of nephrologists and the unavailability of amino and keto acid supplements.
\end{abstract}

Keywords: Low protein diets, Chronic kidney disease, Cameroon, Africa

Abbreviations: CKD, Chronic kidney disease; LPD, Low protein diet

\section{Background}

Cameroon is a low-middle income sub-Saharan African country with a population of 22.5 million and a gross domestic product of 34 billion US dollars [1]. Life expectancy at birth is 58 years, infant mortality is 88 per 1000 births and maternal mortality is 590 per 100,000 live births. Health expenditure constitutes $5.1 \%$ of the gross domestic product, and private health expenditure

\footnotetext{
* Correspondence: maglo09@hotmail.com

${ }^{1}$ Yaounde General Hospital \& Faculty of Medicine and Biomedical Sciences,

University of Yaounde I, Yaounde, Cameroon

Full list of author information is available at the end of the article
}

accounts for $67.6 \%$ of this expenditure, of which $94.2 \%$ is funded by the patients themselves [2]. About $46 \%$ of the population have access to improved sanitation and $47 \%$ live in rural areas. There is a huge deficit in manpower in the healthcare system with less than one physician and 4.4 nurses per 10,000 inhabitants [2].

While the true prevalence of chronic kidney disease (CKD) in Cameroon is unknown, CKD is common, with a prevalence of $13.2 \%$ reported in one region [3]. There has also been a gradual increase in the number of Cameroonians receiving long-term haemodialysis $[4,5]$. Although several measures are known to slow the 
progression of CKD, such as low protein diets (LPDs), the late presentation to nephrologists of patients with CKD often precludes their use. We have previously reported that $55.7 \%$ of patients with CKD are seen for the first time in our clinic at stage 5 , with one third of them requiring emergency dialysis [6].

\section{Food and dietary habits in Cameroon}

The habitual diet of Cameroonians provides a daily energy intake of $14.1-18 \mathrm{MJ}$ with only $8.9-10.4 \%$ of total energy intake from proteins compared to $45.3-48.7 \%$ from carbohydrates and $42.0-43.8 \%$ from fats [7]. In Cameroon, the daily protein intake of adult women has been estimated at $88 \mathrm{~g}$ in rural residents and $86 \mathrm{~g}$ in urban residents. In adult men, the daily protein intake values are higher at $94.5 \mathrm{~g}$ in rural residents and $100.1 \mathrm{~g}$ in urban residents [7]. These values probably represent a daily protein intake of more than $1 \mathrm{~g}$ per $\mathrm{kg}$ bodyweight. In rural areas, dietary proteins are mainly derived from leafy vegetables, legumes, grains, seeds and mushrooms, while in urban areas, animal proteins account for a significant part of protein intake [7-11]. Several studies have confirmed the high protein value of most of the indigenous leafy vegetables, legumes, grains and spices used for food in Cameroon [12-20]. Traditional home meals using staple foods are the mainstay of diets in rural areas, while Western-style foods and takeaway fast foods are becoming increasingly common in urban areas [7, 21]. Indigenous Cameroonian meals are usually prepared as a composite mixture of different foods served as sauces or soups alongside a starchy food [7, 10,16, 18, 21, 22], though occasionally the starchy food is included in the sauce and served as a single dish. These sauces usually contain leafy vegetables, legumes and seeds with meat or fish added depending on affordability, availability and cultural habits. Starchy foods commonly consumed in Cameroon include corn, millet, sorghum, cassava (tubers of Manihot utilissima), yam (tubers of Dioscorea sp.), cocoyam (tubers of Xanthosoma sp.), potatoes, plantains, unripe bananas and rice $[7,8,10$, 11, 16, 21, 23]. Examples of common composite meals and their compositions are shown in Table 1. Meal frequency depends on affordability, usually varying from twice daily in rural areas to thrice daily in urban areas. Meals consumed by rural populations and low-income urban populations typically include breakfast (usually left-overs from the previous supper) and supper. Breakfasts consumed by urban and semiurban populations typically consist of bread and fried mixtures of wheat flour, cassava or corn dough (locally called puff-puff, acra or beignets) eaten with a bean sauce, pap (hot cereal composed of fermented corn, sorghum or millet flour, mixed with water, sugar and lemon), meatballs or an omelette [7, 21]. Breakfasts consumed by the lower and lower-middle class in semi-urban and urban areas are often purchased as fast foods from mobile or roadside restaurants [24].

Uncooked foods are sold mainly in markets that open daily in semi-urban and urban areas and periodically in rural areas. With the exception of beef, pork and fish, which are sold per weight, other indigenous foodstuffs are neither weighed nor labelled. Legumes and cereals are quantified for sale using standard containers for measurement such as $150 \mathrm{ml}$ plastic bowls or empty cans of tomato paste or concentrated milk that are widely available.

\section{Dietary prescription}

Dieticians are scarce in Cameroon and when available are not dedicated to renal patients. Dietary prescriptions for the majority of CKD patients are therefore made by nephrologists who usually lack expertise in renal nutrition and who are often responsible for the care of a large number of patients. Only two of the nine hospitals in Cameroon with renal services have a dietician, and these dieticians service the entire hospital patient population. In a recent survey in our unit, less than a quarter of our patients in the pre-dialysis clinic had consulted a dietician about a renal diet (unpublished data). Nephrologists in Cameroon have thus learnt how to design diets for CKD patients during their clinical practice.

\section{LPDs in Cameroon}

The prescription and design of LPDs in Cameroon are challenging because of resource limitations, a shortage of healthcare personnel and protean dietary practices. In our practice, only moderate LPDs of $0.6 \mathrm{~g}$ protein per $\mathrm{kg}$ bodyweight per day (moderate LPD) and relatively mild LPDs of $0.7-0.8 \mathrm{~g}$ protein per $\mathrm{kg}$ bodyweight per day (mild LPD) are prescribed for CKD patients. Several types of LPD have been well-described including the traditional LPD, vegan LPD, vegan LPD supplemented with amino and keto acids, LPD with protein-free food and a very low protein diet of $0.3 \mathrm{~g}$ protein per $\mathrm{kg}$ bodyweight per day [25]. Only the traditional LPD with mixed protein intake is feasible in Cameroon. Amino and keto acid supplements are not available locally and their cost precludes importation for the majority of patients. The moderate LPD is prescribed to patients with stage 3 or 4 CKD who have non-nephrotic proteinuria, no interrcurrent acute illnesses and no clinical evidence of malnutrition. The mild LPD is prescribed to patients with stage 3 or 4 CKD with nephrotic proteinuria but no signs of malnutrition, CKD with no uremic signs or symptoms and stage 5 CKD on non-dialysis treatment. In the absence of pre-weighed foods and meals, we have devised simple ways of enabling patients to estimate 
Table 1 A selection of some common composite meals in Cameroon

\begin{tabular}{ll}
\hline Meals & Compositions \\
\hline Okra pod soup & A soup that is prepared with fresh okra (Abelmoschus esculentus), dried fish or fresh beef, tomatoes, spices, oil. \\
Ground egusi or peanuts may be added. Usually eaten with garri, corn or cassava fufu \\
Bean stew \\
A stew made of dried beans, tomatoes, crayfish, onions and palm oil. \\
Conga \\
A dish of fresh corn boiled with cassava, huckleberry or pumpkin leaves in palm nut pulp. It is eaten as a meal. \\
A sauce of boiled dry corn grains (Zea mays L) and dry grains of beans (Phaseolus vulgaris), cooked in palm oil \\
(Elaeis guinensis), with limestone, Maggi cube, kitchen salt, onions, ginger, garlic, and crayfish as main ingredients. \\
Bobolo or miondo \\
A paste of fermented cassava (Manihot utilissima) wrapped in leaves and steam boiled. \\
Corn fufu \\
Aarri
\end{tabular}

protein quantities, such as the distribution of photographs of $100 \mathrm{~g}$ portions of meat; fish and chicken to illustrate quantities. We have learnt, for instance, that the drumstick of an average-sized chicken weighs approximately $200 \mathrm{~g}$, and an average egg provides about $6 \mathrm{~g}$ of protein. We have also found published data on the protein content of composite meals similar to those sold in roadside restaurants to be very useful for diet design $[11,16,18,21]$. For instance, data on corn chaff (corn, beans, palm oil, crayfish, salt, Maggi cube), a composite meal commonly sold in roadside restaurants, reveal that it contains $11.7 \mathrm{~g}$ protein per $100 \mathrm{~g}$ and that a serving at these restaurants typically weighs about $640 \mathrm{~g}$ [18].

We do not limit intakes of vegetables, legumes or cereals for patients in rural areas for whom these foods constitute the main source of protein. In this group of patients, animal proteins are only eaten sporadically either during ceremonies or when a wild animal (bush meat) is killed during hunting or incidentally. We do not restrict this occasional animal protein intake either, provided that the prescribed total daily protein intake is not exceeded. For patients who go for several months with no access to animal proteins, we encourage the intake of soya bean at least once a week if available locally. For patients whose habitual diet is rich in animal proteins, we prescribe animal proteins to constitute $50-70 \%$ of the total protein intake, with vegetables, legumes and cereals providing the remainder. This quantity of animal proteins can be consumed daily or on set days. For those patients consuming animal proteins daily, the animal proteins constitute $50-60 \%$ of the total daily protein intake.
For those consuming animal proteins on set days, animal proteins constitute $60-70 \%$ of total daily protein intake on these days and $0 \%$ of total daily protein intake on the other days. Most patients choose 2-3 animal protein free days per week. An example of a 7-day menu for a traditional moderate LPD prescribed to a middle-class Cameroonian residing in an urban area with two animal protein free days is presented in Table 2. Energy requirements and other specific dietary restrictions associated with CKD are taken into consideration when designing the diet. In order to promote adherence to the prescribed diet, we explain the diet to the patients as well as those who prepare their meals (usually the female relatives of male patients, as is the tradition in most indigenous Cameroonian families). Dietary habits, meal frequencies and economic status are also important factors we consider when designing a diet.

\section{Nutritional monitoring of patients}

The reliance on patient funds for healthcare means that we do not request additional clinic visits for patients on LPDs or use multiple Para clinical tests to assess or monitor their nutritional status, because they are generally unaffordable. However, before prescribing the diet, we do evaluate the body mass index of patients without oedema; and perform a subjective global assessment of nutritional status using a validated questionnaire. Para clinical assessments are limited to a serum albumin assay, which may be requested if the patient can afford it. This evaluation is performed at each follow-up visit, with the exception of serum albumin which is requested 
Table 2 A 7-day 0.6 LPD menu for a $60 \mathrm{~kg}$ urban patient in Cameroon

\begin{tabular}{|c|c|c|c|c|c|c|c|}
\hline Meal & Day1 & Day 2 & Day 3 & Day 4 & Day 5 & Day 6 & Day 7 \\
\hline Breakfast & $\begin{array}{l}\text { Beignets and, } \\
\text { beans stew }\end{array}$ & $\begin{array}{l}1 \text { piece of meat }(100 \mathrm{~g}) \\
\text { in } \mathrm{s} \text { cabbage stew with, } \\
\text { onions } \\
\text { Boiled Irish potatoes } \\
\text { or bobolo }\end{array}$ & $\begin{array}{l}1 \text { slice of fresh fish }(50 \mathrm{~g}) \text { in } \\
\text { stewed leafy vegetables } \\
\text { with lots of onions } \\
\text { Boiled Sweet Potatoes }\end{array}$ & $\begin{array}{l}25 \mathrm{~g} \text { of minced meat with } \\
\text { steamed mixed vegetables } \\
\text { and diced boiled lrish potato } \\
\text { in salad }\end{array}$ & $\begin{array}{l}1 / 4 \text { medium avocado, } \\
\text { vegetable salad with } \\
\text { low fat salad dressing } \\
\text { Bread } \\
\text { Tea with sugar }\end{array}$ & $\begin{array}{l}\text { Corn or millet pap, } \\
\text { bread or beignets }\end{array}$ & $\begin{array}{l}1 \text { slice of fish }(50 \mathrm{~g}) \\
\text { in soup } \\
\text { Boiled Plantain or } \\
\text { bobolo }\end{array}$ \\
\hline Lunch & $\begin{array}{l}\text { Stewed local leafy } \\
\text { vegetables with } \\
\text { soyabean or } \\
\text { groundnut paste. } \\
\text { Boiled cocoyam }\end{array}$ & $\begin{array}{l}11 / 2 \text { slices of fresh fish } \\
(70 \mathrm{~g}) \text { with mixed } \\
\text { vegetables in stir fry } \\
\text { Boiled yam }\end{array}$ & $\begin{array}{l}2 \text { tablespoons of ground } \\
\text { crayfish in stewed local } \\
\text { leafy vegetables with lots } \\
\text { of onions } \\
\text { Boiled Irish Potatoes }\end{array}$ & $\begin{array}{l}\text { Mixed local vegetables in or } \\
\text { tomato sauce } \\
300 \mathrm{~g} \text { ( } 15 \text { heaped tablespoons) } \\
\text { of boiled white rice }\end{array}$ & $\begin{array}{l}01 \text { drumstick of skinned } \\
\text { chicken in stewed cabbage } \\
\text { with lots of onions, celery } \\
\text { and leeks } \\
\text { Boiled plantain }\end{array}$ & $\begin{array}{l}\text { Cassava leaves and } \\
\text { palm nut pulp in } \\
\text { soup served with } \\
\text { boiled cassava OR } \\
\text { Sanga }\end{array}$ & $\begin{array}{l}1 \text { slice of steamed fish } \\
(50 \mathrm{~g}) \text { in garden } \\
\text { eggplant leaves in stir fry } \\
\text { Boiled plantains }\end{array}$ \\
\hline Supper & $\begin{array}{l}\text { Vegetable salad } \\
\text { and bread } \\
\text { Lemon grass tea }\end{array}$ & $\begin{array}{l}15 \mathrm{~g} \text { of smoked fish in } \\
\text { okra soup served with } \\
\text { garri }\end{array}$ & $\begin{array}{l}2 \text { tablespoons of soybean } \\
\text { paste in stewed cabbage } \\
\text { Boiled unripe bananas }\end{array}$ & $\begin{array}{l}1 \text { medium chicken drumstick } \\
(100 \mathrm{~g}) \text {, in soup } \\
\text { Boiled Irish potatoes }\end{array}$ & $\begin{array}{l}\text { Egusi or groundnut okra } \\
\text { soup with crayfish } \\
\text { Corn fufu }\end{array}$ & $\begin{array}{l}\text { Mixed vegetables in } \\
\text { tomato sauce } \\
\text { pasta or rice (boiled) }\end{array}$ & $\begin{array}{l}\text { A slice of fresh fish } \\
(50 \mathrm{~g}) \text {, flaked with } \\
\text { melon leaves in stir-fry } \\
\text { Boiled sweet potatoes }\end{array}$ \\
\hline
\end{tabular}

Beignets: deep fried semi-liquid paste of wheat, cassava, and corn or beans flour sweetened with either sugar or banana or salted the; Bobolo: steam boiled paste of fermented cassava (Manihot utilissima roots); Cocoyam: tuber of Xanthosoma sp.; Corn fufu: cooked paste of dried ground corn; Garri: A fine to coarse granular flour made from fermented cassava fried either in palm oil or without palm oil; Irish potatoes: Solanum tubrosum; Okra: Abelmoschus esculentus; Pap: a dish made of hot cereal of fermented corn, sorghum or millet flours and mixed with water, sugar and lemon; Sanga: dish of fresh corn boiled with cassava, huckleberry or pumpkin leaves in palm nut pulp; Sweet potatoes: tuber of Ipomoea batatas; ; Yam: tuber of Dioscorea sp., Egusi: ground melon seeds (Cucumeropsis mannii) 
6-monthly. We have also used haemoglobin and serum phosphorus and cholesterol levels as indicators of nutritional status, measured as part of routine patient care. Adherence to LPD is poor in our practice. Only $36 \%$ of 28 patients prescribed a traditional $0.6-0.8$ LPD in our outpatient clinic were adherent (Unpublished data). In our experience, assessments of patient nutritional status during their routine follow-up visits are sufficient and do not significantly increase consultation time.

\section{Conclusions}

In conclusion, the use of LPDs for CKD patients is challenging in Cameroon. There are no renal dieticians, and the nephrologists who play this role have limited nutritional expertise. Furthermore, the lack of amino and keto acid supplements as well as the composite nature of meals in Cameroon limit the type of LPD that can be prescribed. The high rate of late presentation for care observed in CKD patients and the high personal cost of healthcare precludes the use of this therapy for many patients. Several strategies may increase the use of LPDs in CKD patients in Cameroon, such as improving the knowledge and practice of nephrologists and nurses in nutrition and making amino and keto acid supplements accessible to patients.

Acknowledgements

None.

\section{Funding}

None.

\section{Availability of data and materials}

Not applicable.

\section{Authors' contributions}

GEA: conceived of, designed, collected data, drafted and reviewed the manuscript. HDMF: provided data and critically reviewed the manuscript. FFK: provided data and critically reviewed the manuscript. MPH: collected data and critically reviewed the manuscript. CTA: provided data and reviewed the manuscript. MBS: critically reviewed the manuscript. All authors were involved in drafting and revising the manuscript and have approved the final version and agree to be accountable for all aspects of the work.

\section{Competing interests}

The authors declare that they have no competing interests.

\section{Consent for publication}

Not applicable.

\section{Ethics approval and consent to participate}

Not applicable.

\footnotetext{
Author details

${ }^{1}$ Yaounde General Hospital \& Faculty of Medicine and Biomedical Sciences, University of Yaounde I, Yaounde, Cameroon. Douala General Hospital \& Faculty of Medicine and Biomedical Sciences, University of Yaounde I, Yaounde, Cameroon. ${ }^{3}$ University Teaching Hospital Yaounde \& Faculty of Medicine and Biomedical Sciences, University of Yaounde I, Yaounde, Cameroon. ${ }^{4}$ Douala General Hospital \& Faculty of Medicine and Pharmaceutical Sciences, University of Douala, Douala, Cameroon. ${ }^{5}$ Yaounde Central Hospital, Yaounde, Cameroon. ${ }^{6}$ Faculty of Medicine and Biomedical Sciences, University of Yaounde I, Yaounde, Cameroon.
}

Received: 4 February 2016 Accepted: 29 August 2016

Published online: 07 September 2016

\section{References}

1. Cameroon GDP and Economic Data. Available from: https://www.gfmag. com/global-data/ 282country-data/cameroon-gdp-country-report. Accessed 27 Jan 2016.

2. Cameroon: Index-AHO. Available from http://www.aho.afro.who.int/profiles information/index.php/Cameroon:Index. Accessed 26 Jan 2016

3. Kaze FF, Meto DT, Halle M-P, Ngogang J, Kengne A-P. Prevalence and determinants of chronic kidney disease in rural and urban Cameroonians: a cross-sectional study. BMC Nephrol. 2015;16:117.

4. Kaze FF, Kengne AP, Choukem SP, Dzudie A, Halle MP, Dehayem MY, et al. Dialysis in Cameroon. Am J Kidney Dis. 2008;51:1072-4.

5. Halle MP, Takongue C, Kengne AP, Kaze FF, Ngu KB. Epidemiological profile of patients with end stage renal disease in a referral hospital in Cameroon. BMC Nephrol. 2015;16:59.

6. Halle MPE, Kengne AP, Ashuntantang G. Referral of patients with kidney impairment for specialist care in a developing country of sub-Saharan Africa. Ren Fail. 2009:31:341-8.

7. Mennen LI, Mbanya JC, Cade J, Balkau B, Sharma S, Chungong S, et al. The habitual diet in rural and urban Cameroon. Eur J Clin Nutr. 2000;54:150-4.

8. Nolla NP, Sop MMK, Djeukeu WA, Tetanye EA, Gouado I. Assessment of nutritional status and food consumption in Makepe Missoke, Douala, Cameroon. J Med Sci. 2013;4:1-7

9. Elie F, Roger P, Honoris TDP, Brice DKH, Blonde TL, Bih AM, et al. Methods of preparation and nutritive value of some dishes consumed in the West Region of Cameroon. Pak J Nutr. 2009;8:1190-5.

10. Kouebou CP, Achu M, Nzali S, Chelea M, Bonglaisin J, Kamda A, et al. A review of composition studies of Cameroon traditional dishes: Macronutrients and minerals. Food Chem. 2013;140:483-94.

11. Ponka R, Fokou E, Leke R, Fotso M, Souopgui J, Achu Bih M, et al. Methods of preparation and nutritional evaluation of dishes consumed in a malaria endemic zone in Cameroon (Ngali II). Afr J Biotechnol. 2005;4:273-8.

12. Mawouma S, Ponka R, Mbofung CM. Composition of 13 different traditional sauces prepared from moringa olifera leaves in the far-north region of cameroon. Int J Innov Appl Stud. 2014;7:1129-36.

13. Ejoh RA, Nkonga DV, Inocent G, Moses MC. Nutritional components of some non-conventional leafy vegetables consumed in Cameroon. Pak J Nutr. 2007;6:712-7.

14. Bouba AA, Njintang NY, Foyet HS, Scher J, Montet D, Mbofung CMF. Proximate Composition, Mineral and Vitamin Content of Some Wild Plants Used as Spices in Cameroon. Food Nutr Sci. 2012;03:423-32.

15. Achu MB, Fokou E, Tchiégang C, Fotso M, Tchouanguep FM. Nutritive value of some Cucurbitaceae oilseeds from different regions in Cameroon. Afr J Biotechnol. 2005:4:1329-34.

16. Yadang G, Tchatchueng JB, Tchiegang C. Protein, carbohydrate, fat and energy content of "ready-to-eat foods" in Cameroonian Sahel's region. J Food Technol. 2009;7:1-4.

17. Nkongho GO, Achidi AU, Ntonifor NN, Numfor FA, Dingha BN, Jackai LE, et al. Sweet potatoes in Cameroon: Nutritional profile of leaves and their potential new use in local foods. Afr J Agric Res. 2014;9:1371-7.

18. Ponka R, Fokou E, Fotso M, Achu MB, Tchouanguep FM, et al. Methods of preparation and the energy, protein and mineral values of three Cameroonian dishes: Corn chaff, Nnam Owondo/Ebobolo and Nnam Ngon/ Ebobolo. Afr J Food Agric Nutr Dev. 2005;5:1-13.

19. Yang R-Y, Keding GB. Nutritional contributions of important African indigenous vegetables. In: Shackleton CM, Pasquini MW, Drescher AW, editors. African indigenous vegetables in urban agriculture. London: Earthscan; 2009. p. 105-44

20. Fokou $E$, Achu MB. Preliminary nutritional evaluation of five species of egusi seeds in Cameroon. Afr J Food Agric Nutr Dev (AJFAND). 2004;4:1-11.

21. Sharma S, Claude Mbanya J, Cruickshank K, Cade J, Tanya AK, Cao X, et al. Nutritional composition of commonly consumed composite dishes from the Central Province of Cameroon. Int J Food Sci Nutr. 2007:58:475-85.

22. Sop MMK, Fotso M, Gouado I, Tetanye E, Zollo PA. Nutritional survey, staple foods composition and the uses of savoury condiments in Douala, Cameroon. Afr J Biotechnol. 2008:7:1339-43.

23. Koppert GJ, Dounias E, Froment A, Pasquet P. Food consumption in three forest populations of the southern coastal area of Cameroon: Yassa-MvaeBakola. In: Hladik CM, Hladik A, Linares O, Pagezy H, Semple A, Hadley M, 
editors. Tropical Forest, People and Food: Biocultural Interactions and Applications to Development. Paris: UNESCO; 1993. p. 295-310.

24. Acho-Chi $\mathrm{C}$. The mobile street food service practice in the urban economy of Kumba, Cameroon. Singap J Trop Geogr. 2002;23:131-48.

25. Piccoli GB, Vigotti FN, Leone F, Capizzi I, Daidola G, Cabiddu G, et al. Lowprotein diets in CKD: how can we achieve them? A narrative, pragmatic review. Clin Kidney J. 2015;8:61-70.

Submit your next manuscript to BioMed Central and we will help you at every step:

- We accept pre-submission inquiries

- Our selector tool helps you to find the most relevant journal

- We provide round the clock customer support

- Convenient online submission

- Thorough peer review

- Inclusion in PubMed and all major indexing services

- Maximum visibility for your research

Submit your manuscript at www.biomedcentral.com/submit 